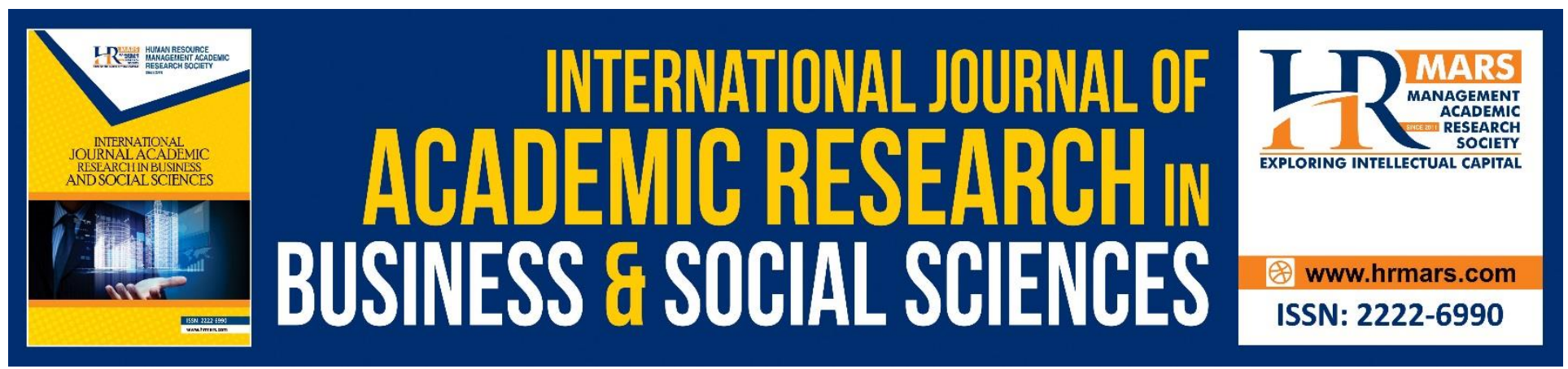

\title{
The Relationship between Aggregate Investment, Investor Sentiment and Stock Returns in Turkey
}

\section{Tulin ANLAS}

To Link this Article: http://dx.doi.org/10.6007/IJARBSS/v8-i10/4774

DOI: $10.6007 /$ IJARBSS/v8-i10/4774

Received: 11 Sept 2018, Revised: 19 Oct 2018, Accepted: 26 Oct 2018

Published Online: 27 October 2018

In-Text Citation: (ANLAS, 2018)

To Cite this Article: ANLAS, T. (2018). The Relationship between Aggregate Investment, Investor Sentiment and Stock Returns in Turkey. International Journal of Academic Research in Business and Social Sciences, 8(10), 707-728.

\section{Copyright: (C) 2018 The Author(s)}

Published by Human Resource Management Academic Research Society (www.hrmars.com)

This article is published under the Creative Commons Attribution (CC BY 4.0) license. Anyone may reproduce, distribute, translate and create derivative works of this article (for both commercial and non-commercial purposes), subject to full attribution to the original publication and authors. The full terms of this license may be seen

at: http://creativecommons.org/licences/by/4.0/legalcode

\section{Vol. 8, No. 10, 2018, Pg. 707 - 728}




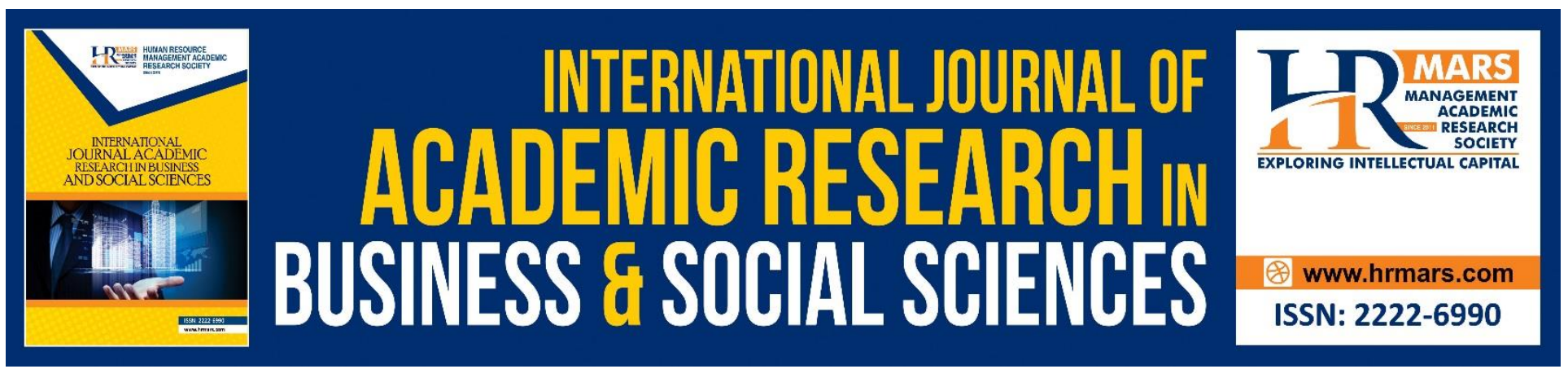

\title{
The Relationship between Aggregate Investment, Investor Sentiment and Stock Returns in Turkey
}

\author{
Tulin ANLAS, PhD \\ Elyaf Iplik A.Ş. (Elyaf Textile Co.), CFO \& Partner \\ Email: tulinanlas@gmail.com
}

\section{ABSTRACT}

By using the financial statement information of the companies listed in BIST (Istanbul Stock Exchange) Industrials Index, I explore the relationship between firm-level investment, investor sentiment and the stock returns for the period of 2004-2014. I use three sentiment measures. First one is the composite investor sentiment index achieved by using the principal component analysis with seven sentiment measures. These investor sentiment proxies are the weighted discount index based on closed-end funds, the changes in the value-weighted discount index, the share of repo holdings in the portfolios of mutual funds, the share of equity issues in aggregate issues, the monthly turnover ratio of BIST, odd-lot sales-to-purchases, net stock purchases of foreign investors-to-BIST market value. Second sentiment measure is the net inflow of investor capital into listed stocks. Third measure is the TUIK (Turkish Statistical Institute) Consumer Confidence Index. The measure of firmlevel investment is based on the change in net operating assets. The results of the fixed effect panel data analysis can be summarised as follows: (i) There is a positive and significant relation between investment and the stock returns. Investment is a better predictor of stock returns than the lagged value of investment. (ii) There is a significant and positive relation between investment and the sentiment index and also between TUIK Consumer and Confidence Index. There is not a significant relation between investment and the net inflow of investor capital into BIST Industrial Index stocks. The results indicate that investment increases during the periods in which investors are more optimistic.

Keywords: Behavioral Finance, Investor Sentiment, Investor Sentiment Index, Aggregate Investment, Consumer Confidence Index, Net Capital Inflow.

\section{INTRODUCTION}

Investor sentiment is optimism or pessimism that is not justified by fundamentals (Arif, 2011). Investor sentiment can also be defined as 'a belief about future cash flows and investment risks that is not justified by the facts at hand' (Baker and Wurgler, 2007). According to Baker and Wurgler (2006, 2007), periods of high investor sentiment line up well with historical accounts of speculative bubbles, 
INTERNATIONAL JOURNAL OF ACADEMIC RESEARCH IN BUSINESS AND SOCIAL SCIENCES Vol. 8, No. 10, Oct. 2018, E-ISSN: 2222-6990 @ 2018 HRMARS

when expectations are buoyant and managers have easy access to investor capital. Today, investment sentiment is generally accepted as a systematic risk factor. Now, the issue is how to measure it. Two methods are used to measure investor sentiment. One is using survey based proxies like consumer confidence indices; the other is using sentiment proxies like investor sentiment indices, weighted discount indices based on closed-end funds, the changes in the value-weighted discount index, the share of repo holdings in the portfolios of mutual funds, the share of equity issues in aggregate issues, odd-lot sales-to-purchases etc.

This study tries to examine whether firm-level investment is associated with investor sentiment in Turkey for the period of 2004-2014. In previous studies, firm-level investment has not been used as an investor sentiment proxy for Turkey. Firm-level investment is found to be a better predictor of investor sentiment for US and for several developed countries as an investor sentiment proxy. For Turkey, I draw on three measures of investor sentiment. The first is the Baker and Wurgler (2006) composite investor sentiment index. Following Baker and Wurgler (2006), I orthogonalize the investor sentiment measures with respect to a set of macroeconomic indicators to remove major macroeconomic influences. The second measure is the TUIK Consumer Confidence Index. This measure has the advantage of directly surveying a large number of households regarding their beliefs. However, the drawback of this survey-based measure is that it does not directly measure investors' actual behavior. Thus, the third measure of investor sentiment I use, is the net inflow of investor capital into BIST Industrials Index listed stocks, based on Dichev (2007). Using Arellano (1987), Froot (1989), Rogers (1993) fixed effect panel data analysis, I tried to find if the level of aggregate investment is related to these three measures of investor sentiment.

\section{LITERATURE REVIEW}

Since 1991, several investor sentiment proxies are used in the literature to examine the relation between investor sentiment and stock returns. Some of them are the proxies like closed-end fund discounts, the number of initial public offerings, the share of equity issues, odd-lot sales-topurchases whereas others are survey based measures like consumer confidence indices. Lee et al. (1991) examine the relation between closed-end fund discounts and stock returns. They find that the discount index is correlated with small stock returns. Leonard and Shull (1996) investigate the investor sentiment effect on New York Stock Exchange (NYSE) stocks by using the discounts of thirtyeight closed-end funds as a proxy for investor sentiment. Investor sentiment is priced for the entire sample period. However, for the subperiods, investor sentiment loses its explanatory power in the second subperiod. Using sixteen Greek closed-end fund discounts as an investor sentiment index, Doukas and Milonas (2004), compare the explanatory power of investor sentiment with that of sector indices. Sector indices are found to be more important than closed-end fund discounts in explaining stock returns.

Neal and Wheatley (1998) regress portfolio returns against three investor sentiment proxies which are the closed-end fund discounts, mutual fund redemptions and the odd-lot sales-to purchases ratio. The closed-end fund discounts and mutual fund redemptions forecast small stock returns whereas the odd-lot sales-to purchases ratio does not affect stock returns. Fisher and Statman (2000), analyse the relation between stock returns and the sentiment of large, medium- 
INTERNATIONAL JOURNAL OF ACADEMIC RESEARCH IN BUSINESS AND SOCIAL SCIENCES Vol. 8, No. 10, Oct. 2018, E-ISSN: 2222-6990 @ 2018 HRMARS

sized and small investor stocks. The sentiments of these three groups of investors seem to forecast future stock returns. Brown et al. (2002) find that an investor sentiment index based on daily mutual fund flow data is significant for both in the United States and Japan. Using various investor sentiment measures, Brown and Cliff (2004) find that investor sentiment measures affect both small and big stock returns. Using the consumer confidence index as an investor sentiment proxy, Lemmon and Portniaguina (2006) find that consumer confidence index has forecasting ability for the small stock returns. Canbas and Kandir (2006) investigate the forecasting ability of investor sentiment measures for BIST sector indices for the period of July 1997-June 2006. Closed-end fund discounts, mutual fund flows and net foreign purchases to BIST capitalization are used as investor sentiment proxies. First, BIST sector indices are regressed against investor sentiment measures. Afterwards, economic variables are added to the first model to control for economic innovations. The results indicate that investor sentiment affects Turkish stock returns, even when economic variables are controlled.

Baker and Wurgler (2006), study how investor sentiment affects the cross-section of stock returns. They construct an investor sentiment index based on six investor sentiment proxies. They predict that a wave of investor sentiment has larger effects on securities whose valuations are highly subjective and difficult to arbitrage. They find that when beginning-of-period proxies for sentiment are low, subsequent returns are relatively high for small stocks, young stocks, high volatility stocks, unprofitable stocks, non-dividend-paying stocks, extreme growth stocks and distressed stocks. When sentiment is high, on the other hand, these categories of stock earn relatively low subsequent returns.

Kandır (2006), investigates the effect of investor sentiment on stock returns by using regression analysis for the period of July 1997 to June 2005. In the regression models, stock portfolio returns are used as dependent variables and investor sentiment proxies are used as independent variables. The results suggest that investor sentiment can forecast stock returns. Stock prices of BIST companies have noise component. The forecasting ability of investor sentiment proxies vary. Whereas the closed-end fund discounts, average fund flow of mutual funds and the ratio of net stock purchases of foreign investors to BIST market capitalization can forecast stock returns significantly; the other proxies cannot.

Schmeling (2008), examines whether consumer confidence, as a proxy for individual investor sentiment, affects expected stock returns internationally in 18 industrialized countries. The results indicate that sentiment negatively forecasts aggregate stock market returns on average across countries. When sentiment is high, future stock returns tend to be lower and vice versa. This relation also holds for returns of value stocks, growth stocks, small stocks, and for different forecasting horizons. The impact of sentiment on stock returns is higher for countries which have less market integrity and which are culturally more prone to herd-like behavior and overreaction.

Canbas and Kandır (2009), investigate the relation between investor sentiment and stock returns on the Istanbul Stock Exchange, employing vector autoregressive (VAR) analysis and Granger causality tests, for the period of July 1997 to June 2005. In the VAR models, stock portfolio returns and investor sentiment proxies are used as endogenous variables. Two dummy variables accounting for natural and economic crises are used as exogenous variables. The results suggest that, excepting shares of equity issues in aggregate issues, stock portfolio returns seem to affect all investor sentiment proxies which are the closed-end fund discount, mutual fund flows, odd-lot sales-to- 
purchases ratio, and repo holdings of mutual funds. Investor sentiment does not appear to forecast future stock returns; only the turnover ratio of the stock market seems to have forecasting potential.

Korkmaz and Cevik (2009), analyse the causality relation between BIST 100 Index return and real sector confidence index. The results of the study indicate that there is a feed-back effect between BIST 100 Index return and confidence index; they simultaneously affect each other.

Stambaugh et.al. (2012), explore the role of investor sentiment in a broad set of anomalies in cross-sectional stock returns. They consider a setting in which the presence of marketwide sentiment is combined with the argument that overpricing should be more prevalent than underpricing, due to short-sale impediments. Long-short strategies that exploit the anomalies exhibit profits consistent with this setting. First, each anomaly is stronger following high levels of sentiment. Second, the short leg of each strategy is more profitable following high sentiment. Finally, sentiment exhibits no relation to returns on the long legs of the strategies.

Baker, et.al. (2011) construct investor sentiment indices for six major stock markets and decompose them into one global and six local indices. In a validation test, they find that relative sentiment is correlated with the relative prices of dual-listed companies. Global sentiment is a contrarian predictor of country-level returns. Both global and local sentiment are contrarian predictors of the time series of cross-sectional returns within markets: When sentiment is high, future returns are low on relatively difficult to arbitrage and difficult to value stocks. Private capital flows appear to be one mechanism by which sentiment spreads across markets and forms global sentiment.

Arif (2011), finds that aggregate corporate investment negatively predicts stock market returns in the US and in ten countries: Japan, the UK, Belgium, Germany, France, Netherlands, Italy, Australia, Singapore and Canada. In Hong Kong, Switzerland and Sweden the coefficient on aggregate investment is negative but not statistically significant. Corporations invest more when: (i) investor sentiment is higher; (ii) the yield curve is flatter; and (iii) analysts are more optimistic about future earnings. Moreover, higher aggregate investment forecasts: (i) lower aggregate ROA; (ii) lower shortwindow returns around earnings announcements; (iii) lower returns on growth stocks and a widening of the 'value premium'; and (iv) deteriorating macroeconomic growth and a higher risk of recession. Several dimensions of these findings are difficult to reconcile in an efficient framework and investment plays a role in driving prices and fundamentals at the aggregate level.

Giray (2012), studies the effect of investment sentiment on asset prices. A sentiment proxy is calculated by performing content analysis on 'the Wall Street Journal's Heard on the Street' columns. This proxy is extracted by the principal component analysis of the word tags from the Harvard psychological dictionary that is used by the content analysis software General Inquirer. The relationship between stock prices, trading volume and the media sentiment proxy is estimated within the VAR context. Results suggest that stock price and trading volume are affected by the media sentiment factor. Findings also imply that stock prices and trading volume in the current time period are mainly affected by the past returns and volume.

Tas and Akdag (2012), relates the changes of trading volume to investor sentiment and investigates its ability in predicting stock returns of all listed equities in the Istanbul Stock Exchange. Results suggest that almost all beta coefficients of volume trend values have positive signs, which reflect the positive contribution of volume changes on the corresponding stock returns. 
Sayim et.al. (2013), examine the effect of rational and irrational investor sentiment on the stock return and volatility of US auto, finance, food, oil and utility industries. The American Association of Individual Investors Index (AAII) is used as a proxy for US individual investor sentiment. The US market fundamentals are regressed on investor sentiment in order to capture the effect of macroeconomic risk factors on investor sentiment. Then impulse response functions (IRFs) are generated from a VAR model to investigate the effect of unanticipated movements in US investor sentiment on both industry-specific stock return and volatility. The results show a significant impact of investor sentiment on stock return and volatility in all the industries. The positive rational component of US individual investor sentiment tends to increase the stock return in these industries. Unanticipated increase in the rational component of US individual investor sentiment has a significant negative impact only on the industry volatilities of US auto and finance industries.

Huang et.al. (2014), propose a new sentiment index that is aligned for explaining stock expected returns by eliminating the noise component. They find that the aligned sentiment index has much greater power in predicting the aggregate stock market than the Baker and Wurgler (2006) index: it increases the $R^{2} \mathrm{~s}$ by more than five times both in-sample and out-of-sample and outperforms any of the well-recognized macroeconomic variables. Its predictability is both statistically and economically significant. Moreover, the new index improves substantially the forecasting power for the cross-section of stock returns formed on industry, size, value, and momentum. Economically, the driving force of the predictive power of investor sentiment appears stemming from market underreaction to cash flow information.

Keles (2015), tries to predict stock returns with investor sentiment by using the residuals derived from time series regressions of consumer and business confidences indexes on macro variables as investor sentiment proxies. Firm-specific characteristics, such as past returns, market capitalization, price to book ratios and dividend yield, and macro indicators are used as control variables in the regressions of return predictability. For Germany and Turkey, sentiment proxies obtained from OECD consumer confidence index predict stock returns strongly for one to three-year periods. Not having significant results for business confidence index shows that it can be a proxy for individual sentiment rather than corporate sentiment. In both of the markets, stocks with higher price to book ratios earn lower returns. Among different BIST portfolios sorted by their price to book ratios, the group with lower ratios earn higher returns following high sentiment periods. Related to past returns of BIST and DAX stocks, long term return reversal, as well as momentum effect in DAX stocks are documented.

Keles and Arat (2016), document a number of sentiment measures and argue the success of the representative indicators in terms of representing sentiment. The study offers deep literature survey about sentiment proxies, reports closed-end fund discounts, Baker and Wurgler composite sentiment index and surveys about consumer confidence/sentiment in detail, and argue their predictive powers in return predictability.

\section{METHODOLOGY}

The research question of this study is if there is a relation between investor sentiment and firm-level investment in Turkey. The data to be used spans from 2004 to 2014. Of the 146 stocks 
listed in BIST Industrial Index, 115 stocks which have continuous data for the period of 2004-2014, are used.

Using the 'top down' approach introduced by Baker and Wurgler (2006), a composite investor sentiment index that captures the common component in the seven proxies, which is modelled as follows, is constructed:

$$
\begin{gathered}
\text { SENTINDEX }_{t}=\beta_{1} \text { DISC }_{t}+\beta_{2} \text { AFLOW }_{t}+\beta_{3} \text { ODDLOT }_{t}+\beta_{4} E_{\text {EUITY }}+\beta_{5} \text { REPO }_{t}+\beta_{6} \text { TURNOVER }_{t}+ \\
\beta_{7} \text { FOREIGN }_{t}+\varepsilon_{t}
\end{gathered}
$$

$D I S C_{t}=$ Changes in the value-weighted index of closed-end fund discounts for the period of t.

AFLOW $t=$ The average flow of all A-type mutual funds for the period of $t$.

ODDLOT $t=$ The ratio of odd-lot sales to purchases for the period of $t$.

EQUITYt= The share of equity issues in aggregate issues for the period of $t$.

$R E P O t=$ The share of repo holdings in portfolios of mutual funds for the period of $t$. TURNOVERt $=$ The BIST turnover ratio for the period of $\mathrm{t}$, computed by dividing the monthly trading volume of BIST by the market value of BIST.

FOREIGN $t$ = The net stock purchases of foreign investors to BIST market value for the period of $t$.

$\varepsilon t=$ Error term.

I estimate the first principal component of the seven proxies and their lags. This gives a firststage index with 14 loadings, one for each of the current and lagged proxies. I then compute the correlation between the first-stage index and the current and lagged values of each of the proxies. Finally, I define SENTIMENT as the first principal component of the correlation matrix of seven variables-each respective proxy's lead or lag, whichever has higher correlation with the first-stage index-rescaling the coefficients so that the index has unit variance.

The investor sentiment proxies for constructing the Baker and Wurgler Index depend on the previous studies in the literature. Lee et. al. (1991) construct a weighted discount index based on the closed-end funds. The weighted discount index is computed as follows:

$$
\begin{aligned}
& \mathrm{VWD}=\sum_{i=1}^{n} W_{t} D I S C_{i t} \\
& W_{i}=\frac{N A V_{i t}}{\sum_{i=1}^{n} N A V_{i t}}
\end{aligned}
$$

where $N A V_{i t}$ is the net assset value of closed-end fund $\mathrm{i}$ at the end of period $\mathrm{t}$.

$$
D I S C_{i t}=\frac{N A V_{i t}-S P_{i t}}{N A V_{i t}} * 100
$$

Where $S P_{i t}$ is the stock price of closed-end fund $\mathrm{i}$ at the end of period $\mathrm{t}$, and $n_{t}$ is the number of closed-end funds at the end of period $t$.

Changes in the value-weighted index of discounts are computed as follows:

$$
\Delta V W D_{t}=V W D_{t}-V W D_{t-1}
$$

I compute mutual fund flows as do Sirri and Tufano (1998):

$$
F L O W_{i t}=\frac{T N A_{i t}-T N A_{i t-1}\left(1+R_{i t}\right)}{T N A_{i t-1}}
$$

where $F L O W_{i t}$ is the flow of fund $\mathrm{i}$ at the end of month $\mathrm{t}$, and $T N A_{i t}$ is the total net assets of fund $\mathrm{i}$ at the end of month t. $R_{i t}$ is computed as follows: 


$$
R_{i t}=\frac{P_{i t}}{P_{i t-1}}-1
$$

where $P_{i t}$ and $P_{i t-1}$ are the share prices of fund $\mathrm{i}$ at the end of months $\mathrm{t}$ and $\mathrm{t}-1$, respectively. The average flow of all A-type mutual funds is computed as below:

$$
\text { AFLOW }_{t}=\frac{1}{n} \sum_{i=1}^{n} \text { FLOW }_{i t}
$$

Brown and Cliff (2004) maintain that the share of cash holdings in the portfolios of mutual funds reflects negative investor sentiment. Their analysis conforms this thought.

Because mutual fund cash holding data is not available in Turkey, I use the share of repo holdings in the portfolios of mutual funds as an investor sentiment proxy. Baker and Wurgler (2006) and Baker and Stein (2004) use the share of equity issues in aggregate issues as a positive investor sentiment proxy. When investor sentiment is positive, the share of equity issues in aggregate issues is expected to increase. In this study, the share of equity issues in aggregate issues is used to proxy investor sentiment. Baker and Wurgler (2006) indicates that the turnover ratio of the stock market reflects investor sentiment and suggest the turnover ratio as a positive investor sentiment proxy. In this study, the monthly turnover ratio of BIST is used as an proxy investor sentiment. The monthly BIST turnover ratio is computed by dividing the monthly trading volume of BIST by the market value of BIST.

Neal and Wheatley (1998) and Brown and Cliff (2004) use the odd-lot sales-to purchases ratio as an investor sentiment proxy. Any rise in this ratio is interpreted as an increase in investor sentiment (Brown and Cliff 2004). In this study, I compute the odd-lot sales-to-purchases ratio simply by dividing odd-lot sales by odd-lot purchases.

The first principal component explains $62.99 \%$ of the sample variance, so I conclude that one factor captures much of the common variation.

Stock returns are adjusted for dividend payments.

The measure of firm-level investment $\left(I N V E S T_{i t}\right)$ I use is based on the change in net operating assets. The change in net operating assets captures net investment in the tangible operating assets of the firm. However, firms also make other investments that are not recognized in financial statements, such as investments in intangible assets arising from research and development (R\&D) activities. To obtain a more comprehensive measure of investment, I extend the measure of investment to include investment in R\&D.

Firm-level investment is computed as follows:

$$
I N V E S T_{i t}=\left(\triangle N O A_{i t}+R \& D_{i t} / 0,5^{*}\left(T A_{i t-1}+R \& D_{i t-1}+T A_{i t}+R \& D_{i t}\right)\right)
$$

$\triangle N O A_{i t}$, is the change in net operating assets, defined as in Dechow et al. (2008) as the change in noncash assets less the change in non-debt liabilities. Noncash assets is calculated as total assets less cash and short term investments. Non-debt liabilities is calculated as total liabilities less debt. TA is total assets, R\&D is research and development expenditure.

Panel data, also known as longitudinal or cross-sectional time-series data, is a dataset in which the behavior of entities are observed across time. Panel data sets have spatial $(\mathrm{N})$ and temporal $(\mathrm{T})$ dimensions. They have a number of observations overtime on a number of cross sectional units such as individuals, firms, etc. This helps analysing the dynamics of change in short time series data. Using 
INTERNATIONAL JOURNAL OF ACADEMIC RESEARCH IN BUSINESS AND SOCIAL SCIENCES Vol. 8, No. 10, Oct. 2018, E-ISSN: 2222-6990 @ 2018 HRMARS

panel data analysis offers several advantages. Inferences can be performed using a larger sample and the lack of degrees of freedom is fairly unlikely to occur. According to Baltagi (2008), more complex relationships can be modelled and temporal changes in cross-section can be analysed. Panel data modelling allows for individual heterogeneity.

A standard approach to model the relationship between the dependent variable $(\mathrm{Y})$ and a set of explanatory variables $(\mathrm{X})$, is modelled below where it is the stochastic error term which takes into account the variation in the expected value of $Y$ which cannot be explained by the $X^{\prime}$ 's.

$$
Y_{i t}=\alpha_{i t}+\beta_{i t} X_{i t}+\varepsilon_{i t}
$$

In a panel data model, the uniqueness of each individual in the sample is captured by $\mu$ i which is the unobserved heterogeneity in the sample as given in the equation below:

$$
Y_{i t}=\mu_{i}+X_{i t}^{\prime} \beta_{i}+\varepsilon_{i t}
$$

In this study, to examine what factors are associated with investment, using Arellano (1987), Froot (1989), Rogers (1993) fixed effect panel data analysis, I estimate equations of the general form: INVEST $_{i t}=\beta_{0}+\beta_{1}$ SENTIMENT $_{i t}+\beta_{2} Q_{i t}+\beta_{3} R_{0 A}+\beta_{4 t} R_{i t}+\beta_{5}$ TERM $_{i t}+\beta_{6}$ TBILL $_{i t}$ $+\beta_{7} O P A C C_{i t}+\varepsilon_{i t}$

where SENTIMENT it is one of three measures of investor sentiment in year $\mathrm{t}$. The first one is the Baker and Wurgler (2006) composite investor sentiment index (SENTINDEX $\left.X_{i t}\right)$. Following Baker and Wurgler (2006), I orthogonalize the investor sentiment measures with respect to a set of macroeconomic indicators to remove major macroeconomic influences. The second measure is the TUIK Consumer Confidence Index $\left(C O N S C O N F_{i t}\right)$. This measure has the advantage of directly surveying a large number of households regarding their beliefs. However, the drawback of this survey-based measure is that it does not directly measure investors' actual behavior. Thus, the third measure of investor sentiment I use is the net inflow of investor capital into BIST Industrials Index listed stocks (INFLOW $W_{i t}$ ), computed following Dichev (2007), scaled by average total assets in year $\mathrm{t}$. Firm-level net capital inflow is the sum of the monthly net capital inflows in year $t$, scaled by average total assets in year $t$ and is computed as:

$$
\text { Inflow }_{i, m}=-1 *\left(M V_{i, m-1} *\left(1+r_{i, m}\right)-M V_{i, m}\right.
$$

where $M V_{i, m}$ is the market capitalization of firm i at the end of month $\mathrm{m}$ and $r_{i, m}$ is the market capitalization of firm $\mathrm{i}$ at the end of month $\mathrm{m}$ (including dividends).

I also include several variables which reflect discount rates and business conditions. Specifically, I include Tobin's $\mathrm{Q}$ at the beginning of year $\mathrm{t}\left(Q_{i t}\right)$, aggregate profitability in year $\mathrm{t}$ $\left(R O A_{i t}\right)$, stock market returns in calendar year $\mathrm{t}\left(R_{i t}\right)$. I also include three variables that reflect interest rates and credit conditions: the term structure of interest rates (TERM $i t)$, measured as the yield spread between ten-year and one-year T-bonds at the beginning of year $t$ ), the 30-day T-bill rate at the beginning of year $\mathrm{t}\left(T B I L L_{i t}\right)$ and operating accruals at year $\mathrm{t}$.

I test the presence of unit root by Levin et al. (2002) (LLC) test, ImPesaran-Shin (IPS) test and Augmented Dickey Fuller (ADF) test. All the variables except for the US Dollar/Turkish Lira exchange rate, are stationary. The US Dollar/Turkish Lira exchange rate becomes stationary when I take its first difference. 
I test for the presence of multicollinearity, heteroskedasticity and autocorrelation. I check the existence of multicollinearity by VIF. I accept that there is multicollinearity among the variables if VIF is greater than 10. In this study, VIF values vary between 1 and 2. There is no multicollinearity problem. The presence of heteroskedasticity is tested by using the modified Wald test. There is heteroskedasticity problem in all the models used in this study. For testing the presence of autocorrelation, I use Bhargava, Franzini and Narendranathan test statistics achieved by calculating the modified panel Durbin-Watson statistics; and Baltagi, Wu Lbi statistic. Both Durbin Watson d statistics and Baltagi-Wu Lbi statistics which are close to two, indicate that there is no autocorrelation in the first order. Adjustments for heteroskedasticity are made by using Arellano (1987), Froot (1989) and Rogers (1993) robust standard errors.

Table 1. Variable Descriptions

\begin{tabular}{|c|c|}
\hline Variables & Description \\
\hline \multicolumn{2}{|c|}{ Dependent Variables } \\
\hline$R$ & $\begin{array}{l}\text { The annual return on the BIST Industrial Index stocks between } 2004 \text { - } \\
2014 \text {, including dividends }\end{array}$ \\
\hline SENTINDEX & $\begin{array}{l}\text { Composite sentiment index, calculated as the first principal } \\
\text { component of seven measures of investor sentiment for the period }\end{array}$ \\
\hline \multirow[t]{2}{*}{ INVEST } & of $2004-2014$ \\
\hline & $\begin{array}{l}\text { Aggregate investment at the firm-level calculated as the change in } \\
\text { net operating assets plus R\&D expenditure, scaled by average total } \\
\text { assets (Net operating assets is total assets less cash and short term } \\
\text { investments minus nondebt liabilities, calculated as total liabilities } \\
\text { less debt) }\end{array}$ \\
\hline$R O A$ & Return on assets, calculated as net income \\
\hline
\end{tabular}

Independent Variables

DISC

REPO

AFLOW

EQUITY

TURNOVER

ODDLOT

FOREIGN

SENTIMENT

CONSCONF

SENTINDEX

INFLOW
Changes in the value-weighed index of closed-end fund discounts The share of repo holdings in the portfolios of mutual funds

The average flow of all A-type mutual funds which have more than $\% 25$ equity in their portfolios

The share of equity issues in aggregate issues

Monthly trading volume of BIST divided by the market value of BIST Odd-lot sales-to-purchases ratio

Net stock purchases of foreign investors/BIST market value

Sentiment measure (One of the variables named CONSCONF, SENTINDEX or INFLOW)

TUIK Consumer Confidence Index/100

Sentiment Index 
INTERNATIONAL JOURNAL OF ACADEMIC RESEARCH IN BUSINESS AND SOCIAL SCIENCES

Vol. 8, No. 10, Oct. 2018, E-ISSN: 2222-6990 @ 2018 HRMARS

Table 1. Variable Descriptions

\begin{tabular}{|c|c|}
\hline Variables & Description \\
\hline INVEST & $\begin{array}{l}\text { Aggregate net capital inflows from investors into listed stocks in year } t \text {, } \\
\text { computed at the firm level, scaled by average total assets in year } t\end{array}$ \\
\hline USDTRY & Investment at the firm level \\
\hline DLNUSDTRY & End of year $t$, USD/TRY exchange rate \\
\hline \multirow[t]{2}{*}{$P / E$} & First order logarithm of end of year $t$, USD/TRY exchange rate \\
\hline & $P / E_{t}$, price-to-earnings ratio at the end of year $\mathrm{t}$ \\
\hline$B / M$ & $B / M_{t}$, book-to-market ratio at the end of year $t$ \\
\hline$D / P$ & Dividend-to-price ratio at the end of year $t$ \\
\hline OPACC & $\begin{array}{l}\text { Operating accruals, computed at the firm level at the end of year } t \text {, divided } \\
\text { by total assets }\end{array}$ \\
\hline$Q$ & $\begin{array}{l}\text { Tobin's } Q=(\text { total market value+Long term debt+Short term debt-Current } \\
\text { Assets)/Total assets }\end{array}$ \\
\hline$R O A$ & Return on assets \\
\hline TBILL & 1 year $t$-bill interest rate at the end of year $t$ \\
\hline TERM & $\begin{array}{l}\text { The difference between } 1 \text { year t-bill and } 10 \text { year t-bond rate at the end of } \\
\text { year } t\end{array}$ \\
\hline
\end{tabular}

\section{RESULTS}

The principal component analysis of the seven proxies and their lags explains $62.99 \%$ of the sample variance, so one factor captures much of the common variation.

Table 2. Principal Component Analysis-SENTINDEX

\begin{tabular}{|c|c|c|c|c|c|}
\hline \multicolumn{6}{|c|}{ Eigen Values } \\
\hline \multirow[b]{2}{*}{ No. } & \multirow[b]{2}{*}{ Value } & \multirow[b]{2}{*}{ Difference } & \multirow[b]{2}{*}{ Ratio } & \multirow{2}{*}{$\begin{array}{r}\text { Cumulative } \\
\text { Value }\end{array}$} & \multirow{2}{*}{$\begin{array}{r}\text { Cumulative } \\
\text { Ratio } \\
\end{array}$} \\
\hline & & & & & \\
\hline 1 & 4.158 .086 & 2.154 .376 & 0.2970 & 4.158 .086 & 0.2970 \\
\hline 2 & 2.003 .710 & 0.542593 & 0.1431 & 6.161 .795 & 0.4401 \\
\hline 3 & 1.461 .116 & 0.266081 & 0.1044 & 7.622 .912 & 0.5445 \\
\hline 4 & 1.195 .035 & 0.214462 & 0.0854 & 8.817 .947 & 0.6299 \\
\hline 5 & 0.980573 & 0.042514 & 0.0700 & 9.798 .520 & 0.6999 \\
\hline 6 & 0.938059 & 0.174732 & 0.0670 & 1.073 .658 & 0.7669 \\
\hline 7 & 0.763328 & 0.190720 & 0.0545 & 1.149.991 & 0.8214 \\
\hline 8 & 0.572607 & 0.077606 & 0.0409 & 1.207 .251 & 0.8623 \\
\hline 9 & 0.495001 & 0.008782 & 0.0354 & 1.256 .752 & 0.8977 \\
\hline 10 & 0.486219 & 0.114597 & 0.0347 & 1.305 .373 & 0.9324 \\
\hline 11 & 0.371621 & 0.042205 & 0.0265 & 1.342 .536 & 0.9590 \\
\hline 12 & 0.329416 & 0.105942 & 0.0235 & 1.375 .477 & 0.9825 \\
\hline 13 & 0.223474 & 0.201719 & 0.0160 & 1.397 .825 & 0.9984 \\
\hline 14 & 0.021755 & --- & 0.0016 & 1.400 .000 & 10.0000 \\
\hline
\end{tabular}


INTERNATIONAL JOURNAL OF ACADEMIC RESEARCH IN BUSINESS AND SOCIAL SCIENCES Vol. 8, No. 10, Oct. 2018, E-ISSN: 2222-6990 @ 2018 HRMARS

Table 2. Eigen Vectors (Loadings)

\begin{tabular}{|c|c|c|c|c|c|c|c|}
\hline & PC 1 & PC 2 & PC 3 & PC 4 & PC 5 & PC 6 & PC 7 \\
\hline DISC & -0.02124 & 29841 & 37429 & 5 & -0.20 & 33 & 94 \\
\hline DISCD & & & & & & & \\
\hline EQUITY & & & & & & & \\
\hline EQUI' & & & & & & & \\
\hline TURN & & & & & & & \\
\hline TUR & & & & 04 & & & \\
\hline ODD & 99 & & 4 & 0.20 & 33 & $-0 . C$ & \\
\hline ODDLOT & 75 & -0.4 & $0.3 c$ & $-0 . C$ & 2 & 0.2 & -0.2 \\
\hline AFLOW & 42 & 0.21 & 0.1 & 0.2 & 37 & 46 & 11 \\
\hline LOW & 8 & 0.2 & 0.0 & 0.2 & 34 & 33 & $-0 . c$ \\
\hline EPO & & 0.01 & 0.00 & -0.0 & & & \\
\hline POD & 51 & 0.0 & & 0.02 & & & \\
\hline FOREIGI & & 0.44 & $0.1 \mathrm{~s}$ & -0.0 & & $0.4 \varepsilon$ & -0.2 \\
\hline \multirow[t]{2}{*}{ FOREIGN } & & & -0.2 & 0.28 & 82 & -0.3 & 0.096815 \\
\hline & PC 8 & 9 & 0 & 1 & 2 & 3 & C 14 \\
\hline SC & & & & 7 & & & \\
\hline $\mathrm{CD}$ & & & & 0.2 & & & $0 .($ \\
\hline UITY & & 0.5 & -0. & -0. & & 0.2 & -0.00993 \\
\hline UITYL & & & 0.3 & 37 & & -0. & 742 \\
\hline $\mathrm{RNC}$ & & 0.1 & & -0.4 & & & -0. \\
\hline RNOI & & 0.01 & -0.0 & 0.3 & & & 0.0 \\
\hline DLOT & 89 & 0.2 & 3 & 0.54 & & 0.1 & \\
\hline DDLOT & & 05 & $0.4 \varsigma$ & -0.3 & 52 & -0 & -0.0 \\
\hline LOW & & & -0.2 & 0.02 & & 6 & 0.0 \\
\hline LOWI & 96 & 7 & & 1 & -0 & 6 & 02 \\
\hline $\mathrm{PO}$ & 58 & 45 & 1 & 7 & 17 & 8 & -0.69817 \\
\hline POD & & & & & & & \\
\hline $\mathrm{FC}$ & & $221<205$ & 0.3 & 0.294 & & 96 & 0.00 \\
\hline & -0.35692 & 0.280029 & 0.461989 & -0.03541 & -0.16414 & 0.106259 & -0.0101 \\
\hline
\end{tabular}

The sentindex can be graphed as in figure 1. 
INTERNATIONAL JOURNAL OF ACADEMIC RESEARCH IN BUSINESS AND SOCIAL SCIENCES Vol. 8, No. 10, Oct. 2018, E-ISSN: 2222-6990 @ 2018 HRMARS

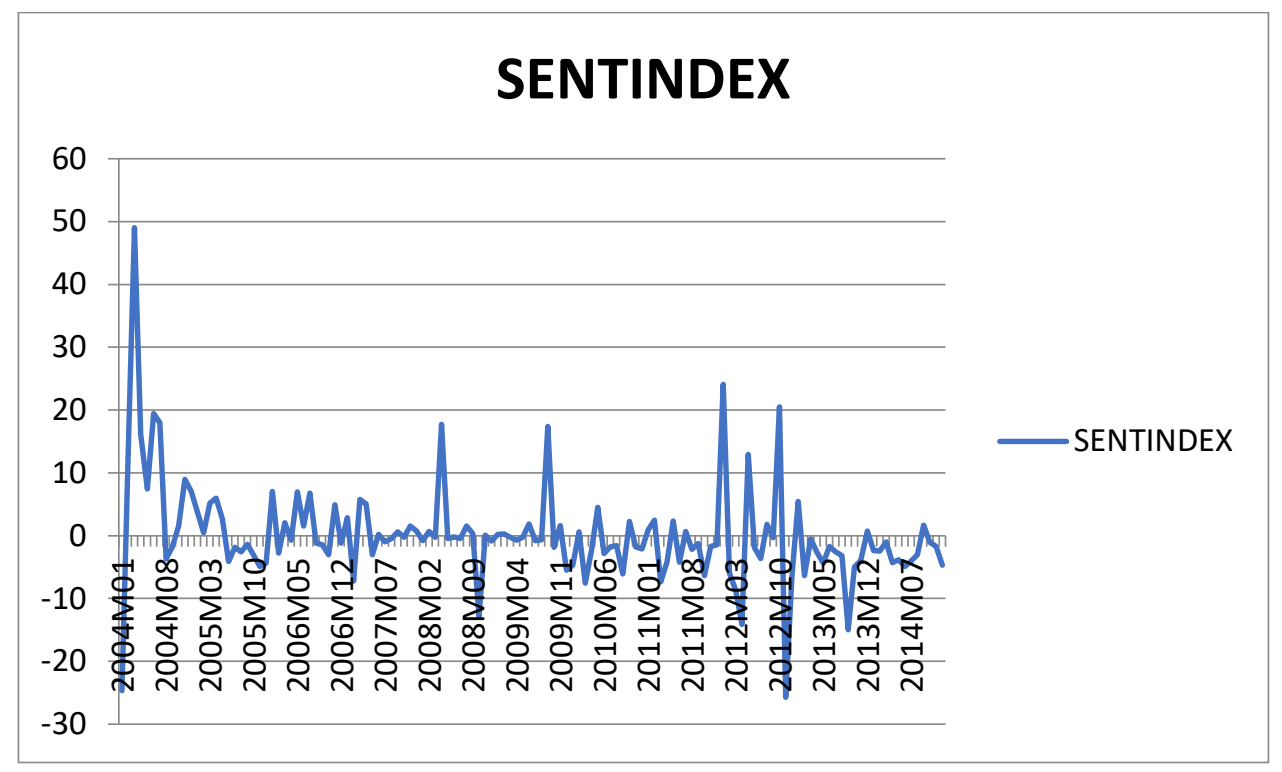

Figure 1. Sentindex in Turkey between 2004:01-2014:12.

Descriptive statistics for the variables used in this study are in Table 3. The mean annual real stock market return is $39.88 \%$ over the sample period. The mean aggregate return on assets (ROA) is 5.37 and mean aggregate investment (INVEST) is 0.079. Net capital inflows from investors to listed stocks (INFLOW) are, on average, negative, with a mean of -1.938 . This indicates that firms tend to distribute more capital to investors than they raise from investors.

Table 3. Summary Statistics

\begin{tabular}{lrrrrr}
\hline Variable & Mean & Std. Deviation & Min & $\begin{array}{r}\text { Max } \\
\text { Obs. } \\
\text { No }\end{array}$ \\
\hline INVEST & & & -0.6505799 & 0.931253 & 1265 \\
INVEST $_{\text {t-1 }}$ & 0.079199 & 0.165146 & -0.6505799 & 0.931253 & 1150 \\
B/M & 0.082125 & 0.168719 & 0 & 74.59702 & 1265 \\
D/P & 1.917556 & 3.646430 & 0 & 76.41019 & 1265 \\
ROA & 0.381874 & 2.977275 & -128.9308 & 70.37128 & 1265 \\
P/E & 5.373117 & 11.23947 & 0 & 10252.55 & 1265 \\
Q & 36.03393 & 311.4279 & -0.33 & 13.21 & 1265 \\
SENTINDEX & 0.927144 & 1.205729 & -6.43737 & 7.1408 & 1265 \\
OPACC & -1.631976 & 3.623272 & -1.220008 & 0.507377 & 1265 \\
INFLOW & -0.022836 & 0.122803 & -566 & 23.9 & 1265 \\
R & -1.937456 & 23.42048 & -0.836066 & 56.6436 & 1265 \\
USDTRY & 0.398775 & 1.774519 & 1.1708 & 2.32095 & 1265 \\
CONSCONF & 1.632227 & 0.342522 & 0.566764 & 0.919449 & 1265 \\
DLNUSDTRY & 0.757091 & 0.093259 & -0.185193 & 0.264602 & 1150 \\
TBILL & 0.054968 & 0.128000 & 0.0587 & 0.2272 & 1265 \\
TERM & 0.128227 & 0.057552 & 0.0001 & 0.0224 & 1265 \\
\hline
\end{tabular}


To predict aggregate returns in Turkey, I estimate the regression

$$
\begin{aligned}
& \text { Rit }=\beta 0+\beta 1 \text { INVESTit }-1+\beta 2 \text { INVEST } i t+\beta 3 \text { TERMit }+\beta 4 \text { TBILLit }+\beta 5 \mathrm{P} / \mathrm{E} i t+\beta 6 \mathrm{~B} / \mathrm{Mit} \\
& +\beta 7 \mathrm{D} / \mathrm{Pit}+\beta 8 D L N \text { USDTRYit }+\beta 9 \text { OPACCit }+\varepsilon t
\end{aligned}
$$

I used the variables suggested by prior literature to predict aggregate stock market returns as control variables. Shiller (1984), Fama and French (1988), Campbell and Shiller (1988), Kothari and Shanken (1997), and Lewellen (2004) examine the dividend-to-price ratio as an aggregate return predictor. Keim and Stambaugh (1986), Fama and French (1989), Pontiff and Schall (1998), Campbell and Vuolteenaho (2003), Hou and Robinson (2006) and Campbell, Polk and Vuolteenaho (2010) investigate the slope of the yield curve as a predictor of aggregate stock returns. Keim and Stambaugh (1986) and Fama and French (1989) analyse the default spread on corporate bonds as a predictor of aggregate stock returns. The results of the studies of Kothari and Shanken (1997) and Pontiff and Schall (1998) show that the book-to-market ratio is a positive predictor of market returns. Baker and Wurgler (2000) indicates that the equity share in new issues is a negative predictor of aggregate returns. Fama and Schwert (1977), Breen et al. (1989), and Ang and Bekaert (2007) indicate that the short rate is a negative predictor of aggregate stock returns. Hirshleifer et al. (2009) show that aggregate accruals positively predicts stock market returns and suggest that aggregate accruals are a discount rate proxy.

Since aggregate investment may have long-term implications for aggregate returns, I included the lag of aggregate investment in the equation. TERM is an indicator of the slope of the yield curve as a predictor of aggregate stock returns. Using fixed effect panel data analysis with Arellano (1987), Froot (1989) and Rogers (1993) robust standard errors, I achieved the coefficients of the variables, robust standard errors, $t$ values and $p$ values in Table 4. 
INTERNATIONAL JOURNAL OF ACADEMIC RESEARCH IN BUSINESS AND SOCIAL SCIENCES Vol. 8, No. 10, Oct. 2018, E-ISSN: 2222-6990 @ 2018 HRMARS

Table 4. Prediction of Aggregate Stock Market Returns in Turkey

\begin{tabular}{|c|c|}
\hline $\begin{array}{l}\text { Dependent } \\
\text { Variable: R }\end{array}$ & Model 1 \\
\hline \multirow[t]{4}{*}{$\mathrm{C}$} & 0.4590916 \\
\hline & 0.0571647 \\
\hline & 8.03 \\
\hline & $(0.000)^{* * *}$ \\
\hline \multirow[t]{4}{*}{ INVEST $_{i t-1}$} & 0.2811999 \\
\hline & 0.2210026 \\
\hline & 1.27 \\
\hline & $(0.206)$ \\
\hline \multirow[t]{4}{*}{ INVEST } & 0.5954533 \\
\hline & 0.2301353 \\
\hline & 2.59 \\
\hline & $(0.011)^{* *}$ \\
\hline \multirow[t]{4}{*}{ TERM } & 29.86568 \\
\hline & 4.244382 \\
\hline & 7.04 \\
\hline & $(0.000)^{* * *}$ \\
\hline \multirow[t]{4}{*}{ TBILL } & -2.938023 \\
\hline & 0.3146396 \\
\hline & -9.34 \\
\hline & $(0.000)^{* * *}$ \\
\hline \multirow[t]{4}{*}{$P / E$} & 0.0000179 \\
\hline & 0.0000145 \\
\hline & -1.23 \\
\hline & $(0.220)$ \\
\hline \multirow[t]{4}{*}{$\mathrm{B} / \mathrm{M}$} & $-2.15 \mathrm{E}-10$ \\
\hline & $2.10 \mathrm{E}-11$ \\
\hline & -10.23 \\
\hline & $(0.000) * * *$ \\
\hline \multirow[t]{5}{*}{$D / P$} & - \\
\hline & 0.0223067 \\
\hline & 0.005198 \\
\hline & -4.29 \\
\hline & $(0.000)^{* * *}$ \\
\hline \multirow[t]{4}{*}{ OPACC } & -0.195748 \\
\hline & 0.267653 \\
\hline & -0.73 \\
\hline & $(0.466)$ \\
\hline \multirow[t]{3}{*}{ DLNUSDTRY } & -1.53476 \\
\hline & 0.1435705 \\
\hline & -10.69 \\
\hline
\end{tabular}


INTERNATIONAL JOURNAL OF ACADEMIC RESEARCH IN BUSINESS AND SOCIAL SCIENCES

Vol. 8, No. 10, Oct. 2018, E-ISSN: 2222-6990 @ 2018 HRMARS

\begin{tabular}{lr} 
& $(0.000)^{* * *}$ \\
\hline $\mathbf{R}^{\mathbf{2}}$ & $\mathbf{0 . 2 0 0 1}$ \\
\hline Significance at $* * \% 1, * * \% 5$ and $* \% 10$ level. &
\end{tabular}

The results indicate that the lag of investment predicts the stock market returns positively. The coefficient of INVEST $_{\text {it-1 }}$ is 0.2811999 . This shows that the periods of high firm-level investment is followed by periods of positive stock market returns. INVEST and stock market returns are also positively related. INVEST (t value: 2.59 ) is a better predictor of stock market returns than INVEST it-1 (t value: 1.27). 1\% increase in INVEST causes \%0.59545 increase in stock market returns. The results of this analysis is in line with the findings of Arif (2011). The significant relation between INVEST it-1 and $\mathrm{R}_{\mathrm{it}}+{ }_{1}$ for US is valid for Turkey between INVEST and $\mathrm{R} . \mathrm{R}^{2}$ value of $20.01 \%$ makes us think that behavioral factors should be considered.

Considering the behavioral factors, Table 5 examines the factors associated with investment using fixed effect panel data analysis with Arellano (1987), Froot (1989) and Rogers (1993) robust standard errors. The coefficients of the variables, robust standard errors, $t$ values and $p$ values can be seen in the table. The dependent variable is $I N V E S T_{i t}$. Three measures of investor sentiment are positively related to investment. Sentiment index and TUIK Consumer Confidence Index are statistically significant. In model 1, ROA and OPACC are the other statistically significant independent variables. In model 2 and 3, TBILL, ROA, OPACC are the other statistically significant independent variables. $R^{2}$ value for model 1 is $23.73 \%$, for model 2 is $23.30 \%$ and for model 3 is $22.88 \%$. According to Table 4, in model 1, $1 \%$ increase in sentindex causes \%0.0058955 increase in investment. In model $2,1 \%$ increase in CONSCONF causes \%0.1060975 increase in investment. In model 3, 1\% increase in inflow causes \%0.0000462 increase in investment. Generally, firm-level investment increases whenever sentiment increases. The results are in line with the study of Arif (2011), Arif and Lee (2014). In US, there is a positive relation between firm-level investment and sentiment. 
INTERNATIONAL JOURNAL OF ACADEMIC RESEARCH IN BUSINESS AND SOCIAL SCIENCES Vol. 8, No. 10, Oct. 2018, E-ISSN: 2222-6990 @ 2018 HRMARS

Table 5. Factors Associated with Firm-level Investment

\begin{tabular}{|c|c|c|c|}
\hline \multicolumn{4}{|l|}{ INVEST } \\
\hline \multirow[t]{4}{*}{ C } & 0.0941431 & -0.025459 & 0.0491139 \\
\hline & 0.0122923 & 0.044814 & 0.014119 \\
\hline & 7.66 & -0.57 & 3.48 \\
\hline & $(0.000)^{* * *}$ & $(0.571)$ & $(0.001)^{* * *}$ \\
\hline \multirow[t]{4}{*}{ SENTINDEX } & 0.0058955 & & \\
\hline & 0.0015045 & & \\
\hline & 3.92 & & \\
\hline & $(0.000)^{* * *}$ & & \\
\hline \multirow[t]{4}{*}{ CONSCONF } & & 0.1060975 & \\
\hline & & 0.0537978 & \\
\hline & & 1.97 & \\
\hline & & $(0.051)^{*}$ & \\
\hline \multirow[t]{4}{*}{ INFLOW } & & & 0.0000462 \\
\hline & & & 0.0001077 \\
\hline & & & 0.43 \\
\hline & & & $(0.669)$ \\
\hline \multirow[t]{4}{*}{$\mathrm{Q}$} & -0.0029965 & -0.0017927 & -0.0026607 \\
\hline & 0.0059791 & 0.0063009 & 0.0061507 \\
\hline & -0.50 & -0.28 & -0.43 \\
\hline & $(0.617)$ & $(0.777)$ & $(0.666)$ \\
\hline \multirow[t]{4}{*}{ TERM } & -0.3319729 & 0.483684 & 0.2254835 \\
\hline & 0.6423419 & 0.7391655 & 0.6886989 \\
\hline & -0.52 & 0.65 & 0.33 \\
\hline & $(0.606)$ & $(0.514)$ & $(0.744)$ \\
\hline \multirow[t]{4}{*}{ TBILL } & 0.0302195 & 0.2064997 & 0.27067 \\
\hline & 0.0914742 & 0.0908664 & 0.0896369 \\
\hline & 0.33 & 2.27 & 3.02 \\
\hline & $(0.742)$ & $(0.025)^{* *}$ & $(0.003)^{* * *}$ \\
\hline \multirow[t]{4}{*}{ ROA } & 0.001591 & 0.0014767 & 0.0015443 \\
\hline & 0.0007019 & 0.0007013 & 0.0006988 \\
\hline & 2.27 & 2.11 & 2.21 \\
\hline & $(0.025)^{* *}$ & $(0.037)^{* *}$ & $(0.029)^{* *}$ \\
\hline \multirow[t]{4}{*}{$\mathrm{R}$} & 0.0016145 & 0.0009705 & 0.0019029 \\
\hline & 0.0026472 & 0.0020792 & 0.0025415 \\
\hline & 0.61 & 0.47 & 0.75 \\
\hline & $(0.543)$ & $(0.642)$ & $(0.456)$ \\
\hline \multirow[t]{4}{*}{ OPACC } & 0.5641812 & 0.5875534 & 0.5887809 \\
\hline & 0.1020202 & 0.1021107 & 0.1028021 \\
\hline & 5.53 & 5.75 & 5.73 \\
\hline & $(0.000)^{* * *}$ & $(0.000)^{* * *}$ & $(0.000) * * *$ \\
\hline
\end{tabular}


INTERNATIONAL JOURNAL OF ACADEMIC RESEARCH IN BUSINESS AND SOCIAL SCIENCES Vol. 8, No. 10, Oct. 2018, E-ISSN: 2222-6990 @ 2018 HRMARS

\begin{tabular}{|c|c|c|c|}
\hline $\mathbf{R}^{2}$ & 0.2373 & 0.2320 & 0.2288 \\
\hline & & & \\
\hline
\end{tabular}

\section{CONCLUSION}

This study tries to make a contribution to the existing literature by exploring the relationship between the firm-level investment and the investor sentiment, and also the relationship between the firm-level investment and the stock returns of the companies listed in BIST Industrials Index for the period of 2004-2014. In the previous studies, firm-level investment has been examined for US and for several developed countries as an investor sentiment proxy, but it has not been used as an investor sentiment proxy for Turkey before. Additionally, I used the net inflow of investor capital into listed stocks and the TUIK Consumer Confidence Index as investor sentiment proxies which have not been used as investor sentiment proxies for Turkey before.

Overall, I used three sentiment measures as investor sentiment proxies. The first one is the composite investor sentiment index achieved by using the principal component analysis with closedend funds, the changes in the value-weighted discount index, the share of repo holdings in the portfolios of mutual funds, the share of equity issues in aggregate issues, the monthly turnover ratio of BIST, odd-lot sales-to-purchases, net stock purchases of foreign investors-to-BIST market value. The other sentiment measures are the net inflow of investor capital into listed stocks and the TUIK Consumer Confidence Index.

The measure of firm-level investment is based on the change in net operating assets. Using Arellano (1987), Froot (1989), Rogers (1993) fixed effect panel data analysis, I achieved the following results:

(i) The lag value of investment predicts the stock market returns positively. The periods of high firm-level investment is followed by periods of positive stock market returns. The firm-level investment in the current period and stock market returns are also positively related. The firm-level investment in the current period is a better predictor of stock market returns than the lagged value of firm-level investment.

(ii) There is a positive and significant relation between investment and the stock returns. Investment is a better predictor of stock returns than the lagged value of investment.

(iii) There is a significant and positive relation between investment and the sentiment index and also between TUIK Consumer and Confidence Index.

(iv) There is not a significant relation between investment and the net inflow of investor capital into BIST Industrial Index stocks. The results indicate that investment increases during the periods in which investors are more optimistic.

The results indicate that investment is positively associated with investor sentiment, even after controlling for factors that may be associated with rational investing. This indicates that behavioral factors play a role in firm-level investment. This relation holds regardless of whether investor sentiment is gauged through surveys of beliefs or inferred from investors' capital market activity. This suggests that behavioral factors play a role in aggregate investment.

Collectively, the evidence is consistent with the ideas of Tugan-Baranovsky (1894), Mises (1912), Hayek (1929), Kindleberger (1978), Minsky (1982) and others. According to these studies, 
periods of aggregate overinvestment are a feature of the business cycle. Such periods are likely to be marked by the easy availability of investor capital, buoyant investor expectations, optimism about future aggregate profitability and growth prospects, and relatively cheap credit. The aggregate stock market, and growth stocks in particular, are overvalued during these periods. Ex-post, the consequences of aggregate overinvestment for fundamentals and asset prices play out. Firms announce disappointing earnings and economy-wide growth falters. In the long run, aggregate profitability declines. Aggregate returns drop, sometimes to the point of falling below the risk-free rate. Growth stocks perform particularly poorly, leading to a widening of the value premium. In short, the inefficient investment results in a macroeconomic bust. Put together, results of this study line up strikingly well with this explanation.

A number of interesting avenues for future research remain. First, which firms or industries are most prone to overinvestment? For example, firms with worse corporate governance may make particularly poor investment decisions. Second, investigating the relation between insider trading and aggregate investment would shed light on whether managers anticipate the negative implications of aggregate investment. Third, it is possible that firms who overinvested the most during periods of aggregate overinvestment may engage in corporate fraud or earnings manipulation to hide their mistakes. Besides, for Turkey the relation between firm-level investment and investor sentiment may be analysed considering the structural breaks. Investigating these issues represent opportunities for future research. 
INTERNATIONAL JOURNAL OF ACADEMIC RESEARCH IN BUSINESS AND SOCIAL SCIENCES

Vol. 8, No. 10, Oct. 2018, E-ISSN: 2222-6990 @ 2018 HRMARS

\section{REFERENCES}

Ang, A. \& Bekaert G. (2007). Stock return predictability: Is it there?, Review of Financial Studies, 20, 651-707.

Arellano, L. (1987). Computing Robust Standart Errors for Within-Groups Estimators, Oxford Bulletin of Economics and Statistics, 49(4), 431-434.

Arif, S. (2011). Aggregate Investment and Its Consequences. Doctoral Dissertation, Stanford University, The Graduate School of Business, Stanford, ss.1-60.

Arif, S. \& Lee C.M.C. (2014). Aggregate Investment and Investor Sentiment. The Review of Financial Studies, 27(11), 3241-3279.

Baker, M. \& Stein, J. C. (2004). Market liquidity as a sentiment indicator. Journal of Financial Markets, 7(3), 271-299.

Baker, M. \& J. Wurgler (2000). The equity share in new issues and aggregate stock Returns. Journal of Finance, 55, 2219-2257.

Baker M. \& Wurgler J. (2006). Investor sentiment and the cross-section of stock returns. The Journal of Finance, 61(4), 1645-1680.

Baker M. \& Wurgler J. (2007). Investor sentiment in the stock returns. Journal of Economic Perspectives, 21(2), 129-152.

Baker, M.P., Wurgler, J. \& Yuan, Y. (2011). Global, Local, and Contagious Investor Sentiment. Journal of Financial Economics, 104(2), 2012; NYU Working Paper No. FIN-09-002. http://ssrn.com/abstract=1415226 (10.04.2014).

Baltagi, B. (2008). Econometric analysis of panel data. John Wiley \& Sons.

Breen W., Glosten L.R. \& Jagannathan R. (1989). Economic Significance of Predictable Variations in

Stock Market Returns. The Journal of Finance, 44(5), 1177-1189.

Brown, S.J., Goetzmann W.N., Hiraki T., Shirashi N. \& Watanabe M. (2002). Investor sentiment in Japanese and US. daily mutual fund flows. Yale ICF Working Paper No. 02-09; Afa 2003 Washington DC Meetings, http://ssrn.com/abstract=302829.

Brown, G.W. \& Cliff M.T. (2004). Investor sentiment and the near-term stock market. Journal of Empirical Finance, 11, 1-27.

Campbell, J. Y. \& Shiller, R. (1988). The dividend-price ratio and expectations of future dividends and discount factors. The Review of Financial Studies, 1:195-228.

Campbell, J.Y. \& Vuolteenaho T. (2003). Bad Beta, Good Beta, Harvard Institute of Economic Research Discussion Paper No: 2016. SSRN: https://ssrn.com/abstract=343780.

Campbell, J.Y., Polk, C. \& Vuolteenaho T. (2010). Growth or Glamour? Fundamentals and Systematic Risk in Stock Returns, Review of Financial Studies, 23(1), 305-344.

Canbas, S. \& Kandir, S. Y. (2006). Hisse Senedi Getirilerinde Yatirimci Psikolojisinin Etkisinin Yatirim Ortakliklari Iskontosu Ile Incelenmesi. Muhasebe ve Finansman Dergisi, (29).

Canbaş S. \& Kandır S.Y. (2009). Investor Sentiment and Stock Returns: Evidence from Turkey. Emerging Markets Finance \& Trade, 45(4), 36-52.

Dechow, P. M., Richardson, S. A. \& Sloan, R. G. (2008). The persistence and pricing of the cash component of earnings. Journal of Accounting Research, 46(3), 537-566.

Dichev, I. (2007). What are stock investors' actual historical returns? Evidence from dollar-weighted returns. American Economic Review, 97(1), 386-401. 
INTERNATIONAL JOURNAL OF ACADEMIC RESEARCH IN BUSINESS AND SOCIAL SCIENCES Vol. 8, No. 10, Oct. 2018, E-ISSN: 2222-6990 @ 2018 HRMARS

Doukas, J.A. \& Milonas N.T. (2004). Investor sentiment and the closed-end fund puzzle: out-of-sample evidence. European Financial Management, 10(2), 235-266.

Fama, E. \& French, K. (1988). Dividend yields and expected stock returns. Journal of Financial Economics, 22, 3-25.

Fama, E. \& French K. (1989). Business conditions and expected returns on stocks and bonds. Journal of Financial Economics, 25, 23-49.

Fama, E. \& Schwert, G. W. (1977). Asset returns and inflation. Journal of Financial Economics, 5, 115146.

Fisher, K.L. \& Statman M. (2000). Investor sentiment and stock returns. Financial Analysts Journal, 56(2), 16-23.

Froot, K. A. (1989). Consistent Covariance Matrix Estimation with Cross-Sectional Dependence and Hetoroskedasticity in Financial Data. Journal of Financial and Quantitative Analysis, 24, 333-355.

Giray, A. (2012). Information in the Financial News: Effect of Market Commentary on Stock Market Performance. Doctoral Dissertation, Orta Doğu Teknik Üniversitesi Sosyal Bilimler Enstitüsü, Ankara, ss.1.

Hayek, F. (1929). Geldtheorie und Konjunkturtheorie 'Monetary Theory and the Trade Cycle', Salzburg.

Hirshleifer, D., Hou K. \& Teoh S. (2009). Accruals, cash flows, and aggregate stock returns. Journal of Financial Economics, 91, 389-406.

Hou, K. \& Robinson, D. (2006). Industry concentration and average stock returns. Journal of Finance, 61(4), 1927-1956.

Huang, D., Jiang, F., Tu, J. \& Zhou, G. (2014). Investor sentiment aligned: a powerful predictor of stock returns. The Review of Financial Studies, 28(3), 791-837.

Kandır, S. Y. (2006). Türkiye'de Yatırıma Duyarlıı̆ıının Hisse Senedi Getirileri Üzerindeki Etkisi. Doctoral Dissertation, Çukurova Üniversitesi Sosyal Bilimler Enstitüsü, Adana, ss.1.

Keim, D. \& Stambaugh, R. (1986). Predicting returns in the stock and bond markets. Journal of Financial Economics, 17, 357-390.

Keleş, E. (2015). Hisse Senedi Getirileri Tahmin Aracı Olarak Yatırımcı Duyarlılığı. Doctoral Dissertation, Marmara Üniversitesi Sosyal Bilimler Enstitüsü, İstanbul, ss.1.

Keleş, E. \& Arat, M. E. (2016). Yatırımc Duyarlıığı Temsilcileri ve Sermaye Getirilerinin Tahmini. Marmara Üniversitesi Öneri Dergisi, 12(45), 307-326.

Kindleberger, C. (1978). Manias, Panics, and Crashes: A History of Financial Crises, New York, NY: Basic Books.

Korkmaz T. \& Çevik E. İ. (2009). Reel kesim güven endeksi ile IMKB 100 arasındaki dinamik nedensellik ilişkisi. İstanbul Üniversitesi işletme Fakültesi Dergisi, 38(1), 24-37.

Kothari S.P. \& Shanken J. (1997). Book-to-market, dividend yield, and expected market returns: A time-series analysis. Journal of Financial Economics, 44, 169-203.

Lee, C.M.C., Shleifer A. \& Thaler R.H. (1991). Investor sentiment and the closed-end fund puzzle. Journal of Finance, 46(1), 75-109.

Lemmon, M. \& Portniaguina E. (2006). Consumer confidence and asset prices: Some empirical evidence. Review of Financial Studies, 19(4), 1499-1529. 
INTERNATIONAL JOURNAL OF ACADEMIC RESEARCH IN BUSINESS AND SOCIAL SCIENCES

Vol. 8, No. 10, Oct. 2018, E-ISSN: 2222-6990 ㄷ 2018 HRMARS

Leonard, D.C. \& Shull D.M. (1996). Investor sentiment and the closed-end fund evidence: impact of the January effect. The Quarterly Review of Economics and Finance, 36(1), 117-26.

Levin, A., Lin C. \& Chu J. (2002). Unit Roots Tests in Panel Data: Asymptotic and Finite Sample Properties. Journal of Econometrics, 108(1), 24-30.

Lewellen, J. (2004). Predicting Returns with Financial Ratios. Journal of Financial Economics, 74(2), 209-235.

Minsky, H. P. (1982). Can it happen again? Essay on instability and finance. New York: ME Sharpe. Mises, L. von (1912). The Theory of Money and Credit, Duncker und Humblot: Leipzig.

Neal, R. \& Wheatley S.M. (1998). Do measures of investor sentiment predict returns. Journal of Financial and Quantitative Analysis, 33(4), 523-547.

Pontiff, J. \& Schall, L. (1998). Book-to-market ratios as predictors of market returns. Journal of Financial Economics, 49, 141-160.

Rogers, W. H. (1993). Regression Standart Errors in Clustered Samples. In Stata Technical Bulletin Reprints, 3, 88-94, College Station, Tx: Stata Press 295.

Sayim M., Morris P.D. \& Rahman H. (2013). The effect of US individual investor sentiment on industryspecific stock returns and volatility. Review of Behavioral Finance, 5(1), 58-76.

Schmeling, M. (2008). Investor sentiment and stock returns: some international evidence. Discussion papers // School of Economics and Management of the Hanover Leibniz University, No. 407.

Shiller, R. J. (1984). Stock prices and social dynamics. Brookings Papers on Economic Activity Review, 2, 457-498.

Sirri, E. R. \& Tufano, P. (1998). Costly search and mutual fund flows. The Journal of Finance, 53(5), 1589-1622.

Stambaugh, R. F., Yu, J. \& Yuan, Y. (2012). The short of it: Investor sentiment and anomalies. Journal of Financial Economics, 104(2), 288-302.

Taş, O. \& Akdağ Ö. (2012). Trading volume trend as the investor's sentiment indicator in Istanbul Stock Exchange. Doğuş Üniversitesi Dergisi, 13(2), 290-300.

Tugan-Baranovsky, M. (1894). Industrial crises in contemporary England, their causes and immediate consequences on national life. I. Schorochodov 